\title{
Kualitas Air Sumur Gali Kelurahan Lubuk Buaya Kecamatan Koto Tangah Kota Padang Berdasarkan Indeks Most Probable Number (MPN)
}

\author{
Randa Novalino ${ }^{1}$, Netti Suharti ${ }^{2}$, Arni Amir $^{3}$
}

\begin{abstract}
Abstrak
Diare merupakan salah satu penyakit yang ditularkan melalui air terkontaminasi oleh agen penyebab seperti bakteri Coliform. Menurut data Dinas Kesehatan Kota (DKK) Padang pada tahun 2011, kejadian diare di Kelurahan Lubuk Buaya Kecamatan Koto Tangah, Kota Padang merupakan kasus tertinggi di Kota Padang. Tujuan penelitian ini adalah menentukan kualitas air sumur gali di Kelurahan Lubuk Buaya berdasarkan Indeks Most Probable Number (MPN) menurut Peraturan Menteri Kesehatan Republik Indonesia (Permenkes RI) No. 416 tahun 1990. Sampel penelitian ini adalah air sumur gali yang digunakan di beberapa Rukun Tetangga (RT), yang diambil secara acak dari beberapa Rukun Warga (RW) yang telah dipilih sebelumnya, sehingga didapatkan 15 sampel. Penelitian ini dilaksanakan dalam 2 tahap yaitu pengambilan sampel air sumur gali sekaligus observasi faktor yang mempengaruhi kualitas air dan pemeriksaan mikrobiologi dengan metode Most Probable Number (MPN) Test. Tes ini terdiri dari tes presumtif dan tes konfirmatif yang disesuaikan dengan Permenkes RI. Hasil penelitian ialah 73,33\% dari jumlah sumur yang diperiksa tidak memenuhi standar Permenkes R.I. karena mengandung Coliform > 50 pada setiap $100 \mathrm{ml}$ air. Hanya 26,6\% sumur yang memenuhi standar yang telah ditetapkan. Beberapa faktor yang dapat mempengaruhi yaitu lokasi sumber pencemaran, dinding parapet, drainase, tutup sumur dan sarana pengambilan air.
\end{abstract}

Kata kunci: kualitas air sumur gali, MPN, coliform

\section{Abstract}

Diarrhea is one of the diseases that transmitted through contaminated water by causative agent, one of which is coliform bacteria. According to data from City Health Department Padang in 2011, the incidence of diarrhea in Kelurahan Lubuk Buaya Kecamatan Koto Tangah - Padang is the highest case in the city of Padang. The objective of this study was to determine the water quality of wells dug in Kelurahan Lubuk Buaya by Most Probable Number Index (MPN) according regulation of Indonesian health minister. The 15 samples was water of dug well in some of the RT households from several neighborhoods that was selected. The research was conducted in two stages, dug well water samples as well as observation of the factors that affect water quality and microbiological examination of the Most Probable Number method (MPN) Test. This test consists of presumptive tests and confirmative tests that were tailored to regulation of Indonesian health minister. The result were $73.33 \%$ of the wells tested did not meet the standards of Indonesian health minister regulation, because it contains $>50$ coliform in every $100 \mathrm{ml}$ of water. Only $26.6 \%$ of the wells were inspected to meet the standards set. Several factors can affect the location of sources of pollution, parapet walls, drainage or sewer water, cover the wells, and water collection facilities.

Keywords: dug well water quality, MPN, coliform

Affiliasi penulis: 1. Prodi Profesi Dokter FK UNAND (Fakultas Kedokteran Universitas Andalas Padang), 2. Bagian Mikrobiologi FK UNAND, 3. Bagian Biologi FK UNAND

Korespondensi: Randa Novalino, email: randa.novalino@ymail.com, Telp: 08526391288

\section{PENDAHULUAN}

Kesehatan lingkungan adalah keseimbangan ekologi yang harus ada antara manusia dan lingkungan agar dapat menjamin keadaan sehat dari manusia. Beberapa ruang lingkup kesehatan daripada 
lingkungan yang penting diantaranya adalah penyediaan air bersih, makanan dan minuman yang higienis dan tindakan pencegahan yang diperlukan untuk menjamin lingkungan. ${ }^{1}$

Penyediaan sumber air bersih harus dapat memenuhi kebutuhan masyarakat, karena persediaan air bersih yang terbatas memudahkan timbulnya penyakit di masyarakat. Batasan sumber air bersih dan aman tersebut antara lain yaitu bebas dari kontaminasi kuman atau bibit penyakit, tidak berasa, tidak berbau, memenuhi standar minimal yang ditetapkan oleh WHO (World Health Organization) atau Departemen Kesehatan Republik Indonesia. ${ }^{2}$

Menurut Permenkes R.I. Nomor: 416 tahun 1990 tentang Syarat-Syarat dan Pengawasan Kualitas Air, menjelaskan bahwa air bersih adalah air yang digunakan untuk keperluan sehari-hari, yang kualitasnya memenuhi syarat-syarat kesehatan dan dapat diminum apabila telah dimasak. Syarat kesehatan mengenai kualitas air yang dimaksud meliputi persyaratan mikrobiologi, fisika, kimia dan radioaktif. ${ }^{3}$ Ketentuan WHO dan APHA (American Public Health Association) menyatakan kualitas mikrobiologis air ditentukan berdasarkan ada atau tidaknya bakteri $E$. coli di dalam air dan jumlah bakteri tersebut di dalamnya. ${ }^{4}$ Kualitas air pada sarana air bersih yang bukan perpipaan atau sumur gali, yang aman untuk digunakan masyarakat berdasarkan paramater mikrobiologi adalah tidak mengandung bakteri koliform lebih dari 50 pada setiap $100 \mathrm{ml}$ air bersih, sedangkan air minum yang aman untuk dikonsumsi masyrakat adalah tidak mengandung bakteri koliform setiap $100 \mathrm{ml}$ air bersih. ${ }^{3}$ Bakteri koliform, termasuk di dalamnya fecal coliform, eschericia coli, klebsiela dan lain-lain, pada umumnya hanya terdapat pada kotoran manusia atau hewan, dan tidak terdapat pada air yang bersih.,

Salah satu penyakit infeksi yang sering disebabkan oleh bakteri koliform adalah diare. Diare merupakan penyakit yang terjadi ketika terdapat perubahan konsistensi feses dan frekuensi buang air besar. Feses lebih berair dari biasanya atau jika buang air besar tiga kali atau lebih, bisa juga buang air besar yang berair tapi tidak berdarah dalam waktu 24 jam. ${ }^{7}$ Mikroorganisme pathogen penyebab diare tersebut masuk bersama dengan makanan atau minuman dan melekat pada sel mukosa usus halus kemudian menimbulkan gangguan. 8 Air merupakan zat yang paling penting bagi manusia terutama digunakan untuk keperluan hidup sehari-hari, seperti untuk minum, memasak, mencuci, mandi dan lain sebagainya. Begitu pentingnya kebutuhan manusia akan air, maka salah satu penyebaran bakteri koliform yang patut untuk diwaspadai adalah melalui sarana penggunaan air. Penularan penyakit infeksi pada air yang tidak bersih atau tercemar bisa terjadi melalui : water born / air minum, water washed / peralatan rumah tangga, water based / penampungan air dan beberapa vektor yang berhubungan dengan air. Salah satu sumber air bersih yang masih banyak digunakan masyarakat sampai sekarang ini adalah sumur gali. ${ }^{2}$

Sumur gali untuk sumber air bersih adalah sarana untuk menyadap dan menampung air tanah dari akuifer, yang dipergunakan sebagai sumber air sebanyak minimal 400 liter setiap hari perkeluarga, dibuat dengan cara menggali. ${ }^{9}$ Sumur gali ini merupakan salah satu sumber air yang tertua di dunia dan masih dipakai oleh masyarakat sampai sekarang. ${ }^{10}$ Sumur ini menyediakan air yang berasal dari air tanah yang relatif dekat pada tanah permukaan, sehingga mudah terkena kontaminasi melalui perembasan dari sumber pencemar. ${ }^{11}$ Untuk itu, sumur gali harus memenuhi persyaratan sanitasi dan terlindung dari kontaminasi air kotor diantaranya yaitu lokasi sumur harus berjarak minimal 15 meter dan terletak lebih tinggi dari sumber pencemaran seperti kakus, kandang ternak, tempat sampah, dan sebagainya, serta berbagai persyaratan lainnya. ${ }^{2}$ Pada beberapa penelitian menyatakan bahwa masih terdapat pencemaran terhadap sarana air bersih sumur gali, yaitu pencemaran bakteri Coliform yang mencapai 35\%, sehingga dikhawatirkan akan menimbulkan dampak yang merugikan di masyarakat. $^{12}$ Untuk mengetahui jumlah bakteri patogen pada air, yaitu bakteri coliform, sampai saat ini masih digunakan metode tabel Hopkins atau yang lebih dikenal dengan nama MPN (Most Probable Number) atau JPT (Jumlah Perkiraan Terdekat). Tabel tersebut dapat digunakan untuk memperkirakan jumlah bakteri coliform didalam $100 \mathrm{ml}$ contoh air yang 
positif terhadap uji penduga (presumptive test), uji penegas (confirmative test) dan uji pelengkap (complete test), dengan menggunakan perlakuan pada $10 \mathrm{ml}, 1 \mathrm{ml}$ dan $0,1 \mathrm{ml}$ contoh air tersebut. ${ }^{4}$ Metode inilah yang akan diterapkan untuk menilai kualitas air sumur gali menurut persyaratan mikrobiologi.

Menurut Data Tabulasi Dasar (DTD) Riset Kesehatan Dasar tahun 2010 pada profil kesehatan indonesia menunjukkan bahwa diare termasuk dalam 10 penyakit terbanyak yang ditemukan di Indonesia, serta membutuhkan perwatan lebih lanjut dari rumah sakit berupa rawat inap maupun rawat jalan. ${ }^{13}$

Di Sumatra Barat terutama daerah kota Padang, berdasarkan data yang dihimpun dari puskesmas-puskesmas di kota Padang, kasus diare sampai saat ini masih termasuk dalam urutan 10 penyakit terbanyak di kota Padang tahun 2010, dengan jumlah kasus yang ditemukan sebanyak 12.744 kasus atau 4,0\% dari semua jumlah penyakit yang ada. Jumlah kasus diare tertinggi terdapat di Puskesmas Lubuk Buaya dengan jumlah penderita sebanyak 1115 orang. ${ }^{7}$ Menurut data laporan hasil kegiatan di wilayah kerja Puskesmas Lubuk Buaya, kelurahan Lubuk Buaya merupakan kelurahan dengan kasus diare tertinggi di wilayah kerja Puskesmas Lubuk Buaya dengan angka kejadian 470 kasus selama satu tahun terkahir. ${ }^{14}$

Tingginya kasus diare di Kelurahan Lubuk Buaya Kecamatan Koto Tangah Kota Padang, berkaitan dengan infeksi kuman patogen pada masyarakat di daerah tersebut yang dicurigai berhubungan dengan kualitas air sumur gali yang tidak memenuhi syarat. Sumur gali merupakan salah satu jenis sarana air bersih yang masih banyak digunakan masyarakat Kelurahan Lubuk Buaya untuk keperluan sehari-hari, seperti untuk minum, memasak, mencuci, mandi dan lain sebagainya. Sebanyak 1677 sumur gali dimanfaatkan oleh 10.293 orang masyarakat di daerah tersebut sebagai sarana air bersih untuk keperluan sehari-hari. ${ }^{15}$ Beberapa sumur gali yang diamati masih banyak ditemukan sumur gali yang tidak memenuhi persyaratan, seperti jaraknya berdekatan (<10 meter) dengan sumber pencemaran (seperti tangki septik), dan terdapat juga konstruksi sumur yang kurang baik sehingga akan mempengaruhi kualitas air sumur.
Kualitas air sumur gali yang dinilai berdasarkan persyaratan mikrobiologis tersebut menjadi faktor yang berpotensi terhadap kejadian diare di Kelurahan Lubuk Buaya, Kecamatan Koto Tangah, Kota Padang.

\section{METODE}

Penelitian ini menggunakan metode deskriptif laboratorium untuk mengetahui kualitas air sumur gali berdasarkan persyaratan mikrobiologi. Penelitian ini dilakukan di Kelurahan Lubuk Buaya, Kecamatan Koto Tangah, Kota Padang, dan dianalisis di laboratorium Mikrobiologi Fakultas Kedokteran Universitas Andalas dari April sampai Juni 2012. Populasi penelitian adalah sumur gali yang terdapat pada beberapa RRT, yang dipilih dari beberapa RW di Kelurahan Lubuk Buaya, Kecamatan Koto Tangah, Kota Padang, berjumlah 180 sumur. Sampel penelitian adalah air sumur gali yang digunakan KK (Kepala Keluarga) di beberapa Rukun Tetangga (RT), yang diambil secara acak dari beberapa Rukun Warga (RW) yang telah dipilih sebelumnya, juga secara acak, di Kelurahan Lubuk Buaya. Teknik pengambilan sampel dilakukan secara gugus bertahap (multy stage random sampling) sebanyak 15 sampel. Besarnya sampel pada penelitian ini ditentukan metode multy stage random sampling dengan KK di beberapa RT sebagai primary sample unit. Dimana dari 1 kelurahan yang terdiri dari 21 RW yang ada di Kelurahan Lubuk Buaya ini, diambil secara acak sebanyak 4 RW (20\% dari jumlah RW). Dari masing-masing RW yang terpilih, diambil sampel secara acak sebanyak 1 RT (20\% dari jumlah RT pada masing-masing RW). Satu RT yang terpilih diperoleh daftar KK yang menggunakan sumur gali, kemudian untuk mengambil sampel dari daftar tersebut yaitu dipilih secara acak dan penentuan besarnya sampel dengan menggunakan rumus estimasi proporsi: ${ }^{16}$

$$
\mathrm{n}=\frac{\mathrm{Z}^{2}{ }_{1-\alpha / 2} P Q}{\mathrm{~d}^{2}}=\frac{1,282^{2} \cdot(0,1)(1-0,1)}{0,1^{2}}=14,7 \approx 15
$$

Keterangan:

$$
\begin{aligned}
& \mathrm{N} \quad=\text { Besar Sampel } \\
& Z^{2}{ }_{1-\alpha / 2}=\text { Derajat kepercayaan } 90 \%=1,282 \\
& \mathrm{P}=\text { Proporsi untuk sifat tertentu yang } \\
& \mathrm{Q} \quad=1-\mathrm{P} \\
& \text { d = Tingkat kepercayaan/ketepatan yang } \\
& \text { dinginkan (10\%) }
\end{aligned}
$$


Berdasarkan perhitungan tersebut, untuk masing-masing RT dibutuhkan sumur untuk sampel penelitian sebanyak 3 sampai 4 buah sumur.

Kriteria sampel:

a. Kriteria inklusi:

Sumur gali yang terdapat di rumah penduduk di Kelurahan Lubuk Buaya.

b. Kerteria eksklusi:

Sumur gali yang tidak diperbolehkan oleh pemiliknya untuk dijadikan sampel.

Sumur gali di rumah penduduk yang tidak digunakan lagi oleh masyarakat.

Penelitian dilakukan dengan terlebih dahulu mengobservasi beberapa faktor yang mungkin mempengaruhi kualitas air, kemudian melakukan pemerikaan mikrobiologi dengan menggunakan Most Probable Number Test yang terdiri dari presumptive test menggunakan medium lactose broth, confirmative test menggunakan medium Brilliant green lactose broth. Pelaksanaan analisis dilakukan berdasarkan metode standar dari $A P H A$, yaitu untuk mengetahui jumlah bakteri Coliform digunakan tabel Hopkins yang lebih dikenal dengan nama tabel Jumlah Perkiraan Terdekat (JPT). Tabel dapat digunakan untuk memperkirakan jumlah bakteri koliform dalam $100 \mathrm{ml}$ sampel air. ${ }^{4}$

HASIL

Tabel 1. Data sampel

\begin{tabular}{cl}
$\begin{array}{c}\text { Sampel } \\
\text { Nomor }\end{array}$ & \multicolumn{2}{c}{ Alamat } \\
\hline 1 & RW 02 RT 03 (Belakang Pasar Kelurahan \\
2 & Lubuk Buaya, Kecamatan Koto Tangah, Kota \\
3 & Padang) \\
4 & \\
\hline 5 & RW 10 RT 03 (Komp. LB. Gading I - Masjid Al \\
6 & AMIN) Kelurahan Lubuk Buaya, Kecamatan \\
7 & Koto Tangah, Kota Padang \\
8 & \\
\hline 9 & RW 09 RT 01 Kompleks Pondok Pinang, \\
10 & Kelurahan Lubuk Buaya, Kecamatan Koto \\
11 & Tangah, Kota Padang \\
12 & \\
\hline 13 & RW 16 RT 01 Kelurahan Lubuk Buaya, \\
14 & Kecamatan Koto Tangah, Kota Padang \\
15 & \\
\hline
\end{tabular}

Tabel 2. Hasil pemeriksaan uji penduga (Presumptive Test)

\begin{tabular}{cccc}
\hline Pengenceran & Positif & Negatif & $\begin{array}{c}\text { Jumlah } \\
\text { Tabung }\end{array}$ \\
\hline \multirow{2}{*}{$0,1 \mathrm{cc}$} & $\begin{array}{c}26 \text { tabung } \\
(19,25 \%)\end{array}$ & $\begin{array}{c}19 \text { tabung } \\
(14,07 \%)\end{array}$ & 45 tabung \\
& 35 tabung & 10 tabung & 45 tabung \\
$1 \mathrm{cc}$ & $(25,92 \%)$ & $(7,40 \%)$ & \\
& 41 tabung & 4 tabung & 45 tabung \\
\multirow{2}{*}{$10 \mathrm{cc}$} & $(30,37 \%)$ & $(2,96 \%)$ & \\
\hline \multirow{2}{*}{ Total } & 102 tabung & 33 tabung & 135 tabung \\
& $(75,55 \%)$ & $(25,92 \%)$ & \\
\hline
\end{tabular}

Tabel 3. Hasil uji penegas (Confirmative test) dicocokkan dengan nilai MPN

\begin{tabular}{ccccc}
\hline Sampel & \multicolumn{3}{c}{ Pengenceran } & \multirow{2}{*}{ Nilai MPN } \\
\cline { 2 - 4 } Nomor & $\mathbf{1 0} \mathbf{c c}$ & $\mathbf{1} \mathbf{c c}$ & $\mathbf{0 , 1} \mathbf{~ c ~}$ & \\
\hline 1 & +++ & ++ & ++ & 210 \\
3 & +++ & +++ & +++ & 2400 \\
4 & +++ & ++ & ++ & 210 \\
5 & +++ & +++ & +++ & 2400 \\
6 & +++ & +++ & + & 460 \\
7 & +++ & + & & 3 \\
8 & +++ & +++ & +++ & 2400 \\
9 & +++ & +++ & ++ & 1100 \\
10 & +++ & +++ & ++ & 1100 \\
11 & + & 0 & + & 7 \\
12 & +++ & +++ & ++ & 1100 \\
13 & 0 & 0 & 0 & 0 \\
14 & +++ & +++ & +++ & 2400 \\
15 & +++ & ++ & 0 & 93 \\
\hline & & & &
\end{tabular}

Pada Tabel 2 dapat dilihat bahwa setelah dilakukan uji penegasdan dicocokkan dengan tabel $M P N$ sesuai metode standar dari APHA, terdapat 1 sampel yang tidak terkontaminasi oleh Coliform (MPN $=0$ ), yaitu sampel nomor 13. Sedangkan 14 sampel lainnya terkontaminasi oleh Coliform $(M P N>0) .14$ Sampel yang terkontaminasi, didapatkan 3 sampel dengan nilai $M P N<50$, yaitu sampel nomor $6(M P N=$ 3), $7(M P N=43)$, dan $11(M P N=7)$. 


\section{Hasil Pemeriksaan indeks MPN air sumur gali sesuai Permenkes RI}

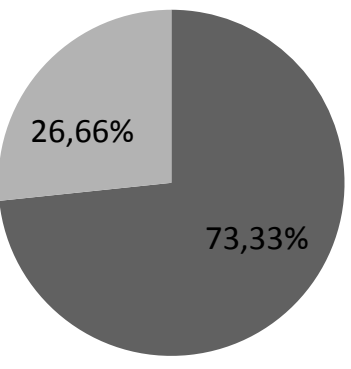

- Tidak

memenuhi

standar

Memenuhi standar

Pada Tabel 4, berdasarkan observasi yang dilakukan ketika pengambilan sampel, $73 \%$ dari jumlah sampel yang diperiksa memiliki sumur gali yang berjarak <10 meter dari sumber pencemaran (kakus, septitank, dan tempat sampah). Sisanya memiliki jarak \pm 10 meter dari sumber pencemaran. Sebanyak $46 \%$ sumur gali yang diperiksa memiliki tutup sumur permanen yang terbuat dari semen. Sisanya sebanyak $54 \%$ sumur gali hanya ditutup dengan seng atau kardus. Kondisi drainase sumur gali yang diperiksa juga berpengaruh terhadap kualitas air sumur gali. Terdapat $46 \%$ sumur gali tidak memiliki saluran pembuangan air atau dibuat seadanya saja. Sebanyak 54\% memiliki saluran pembuangan air ke selokan atau parit. Terdapat $54 \%$ dari jumlah sumur gali yang diperiksa menggunakan ember sebagai sarana pengambilan air. Sisanya menggunakan pompa listrik yang dialiri ke kran air sebagai sarana pengambilan air dengan persentase sebanyak $46 \%$.

\section{PEMBAHASAN}

Pemeriksaan yang dilakukan terhadap 15 sampel air sumur gali di Kelurahan Lubuk Buaya Kecamatan Koto Tangah, Kota Padang, didapatkan satu sampel tidak terkontaminasi Coliform, yaitu sampel nomor $13(M P N=0)$ seperti yang terlihat pada Tabel 3. Sisanya 14 sampel yang didapatkan terkontaminasi terhadap bakteri tersebut. Menurut Permenkes R.I. No. 416/Menkes/Per/IX/1990, tentang Syarat-syarat dan Pengawasan Kualitas Air, bahwa kualitas air pada sarana air bersih sumur gali yang aman untuk digunakan masyarakat berdasarkan persyaratan Mikrobiologi adalah tidak mengandung bakteri koliform lebih dari 50 pada setiap $100 \mathrm{ml}$ air bersih. $^{3}$ Pemeriksaan terhadap 15 sampel air sumur gali di Kelurahan Lubuk Buaya ini dengan metode MPN didapatkan hanya 4 sampel yang memenuhi persyaratan Permenkes tersebut dan layak digunakan masyarakat, yaitu dengan nilai $M P N<50$. Ketiga sampel tersebut yaitu sampel nomor $6(M P N=3)$, sampel nomor $7(M P N=43)$, sampel nomor $11(M P N$ $=7)$, dan sampel nomor $13(M P N=0)$. Sebelas sampel 
lainnya tidak memenuhi persyaratan mikrobiologi sesuai yang ditetapkan Permenkes dan dinyatakan tidak layak digunakan oleh masyarakat. Secara keseluruhan kandungan Coliform pada air sumur gali yang tidak memenuhi standar sebanyak 73,33\%. Temuan ini berbeda dengan hasil penelitian tentang kualitas air sumur gali sebelumnya. Hasil penelitian yang dilakukan oleh Yuniarno di Solo menemukan bahwa terdapat pencemaran bakteri Coliform yang mencapai 35\% pada sarana air bersih sumur gali. Perbedaan ini terjadi karena pada penelitian yang dilakukan oleh Yuniarno terdapat $>50 \%$ sumur gali berjarak lebih dari 10 meter dari sumber pencemaran, seperti kakus, septitank, dan tempat pembuangan sampah, sedangkan sisanya tidak memenuhi standar karena berjarak lebih dekat dari sumber pencemaran (<10 meter). ${ }^{12}$ Penelitian ini mendapatkan bahwa $73,33 \%$ sumur gali yang diperiksa terletak lebih dekat ( $<10$ meter) dari sumber pencemaran dan yang berjarak >10 meter hanya $26,66 \%$.

Hasil pemeriksaan laboratorium, didapatkan satu sampel tidak terkontaminasi coliform, yaitu sampel nomor $13(M P N=0)$. Berdasarkan observasi, didapatkan bahwa sumur gali pada sampel tersebut memiliki tutup sumur yang dibuat permanen dari batu dan semen, pembuangan air atau drainase yang dibuat mengarah ke parit, menggunakan pompa listrik dan dilengkapi alat penyaring khusus, serta faktor penting lainnya yaitu jarak sumur gali terhadap sumber pencemaran yang lebih dari 15 meter. Penggunaan pompa listrik dan dilengkapi dengan alat penyaring ini menjadi kelebihan dibanding sampel sumur gali yang lain, sehingga meningkatkan kualitas air sumur gali pada sampel yang menggunakan alat tersebut. Faktor tersebut yang berpengaruh terhadap kualitas air sumur gali secara mikrobiologi sehingga air sumur gali terhindar dari kontaminasi coliform. ${ }^{2}$

Terjadinya kontaminasi pada sarana air bersih sumur gali melebihi standar yang telah ditentukan pada 11 sampel lainnya, dipengaruhi oleh beberapa faktor yang telah dijelaskan sebelumnya seperti pada Tabel 3.

Pada Tabel 4 dapat dilihat bahwa dari hasil pemeriksaan didapatkan $73,33 \%$ sumur gali berlokasi dekat dengan sumber pencemaran (kakus, septitank, dan tempat pembuangan sampah). Ini sebanding dengan hasil yang didapatkan dari pemeriksaan laboratorium mikrobiologi yang menunjukkan $73,33 \%$ sampel tidak memenuhi standar yang telah ditetapkan Permenkes, yaitu Coliform $>50$ pada setiap $100 \mathrm{ml}$ air bersih. Sisanya sebanyak $26,66 \%$, yang berjarak $>10$ meter dari sumber pencemaran, menunjukkan jumlah Coliform tidak lebih dari 50 pada setiap $100 \mathrm{ml}$ air bersih sesuai standar yang telah ditetapkan. Hal ini menunjukkan bahwa jarak sumber pencemaran terhadap lokasi sumur gali sangat berpengaruh terhadap kontaminasi koliform, sehingga sangat perlu diperhatikan dalam penentuan air sumur gali yang baik harus berlokasi lebih dari 10 meter dari sumber pencemaran. $^{2,9}$

Penggunaan pompa listrik atau ember juga turut mempengaruhi kualitas mikrobiologi air sumur gali. $^{2,9}$ Air sumur gali yang memenuhi standar (Coliform < 50 pada $100 \mathrm{ml}$ air) menggunakan pompa listrik sebagai sarana pengambilan air. Hal ini lebih mengurangi resiko kontaminasi oleh bakteri dibandingkan dengan menggunakan ember. ${ }^{2}$ Sedangkan sebagian besar air sumur gali yang tidak memenuhi standar menggunakan ember sebagai sarana pengambilan air, yaitu sebanyak $63,6 \%$ dari jumlah sumur gali yang tidak memenuhi standar, seperti yang terlihat pada Tabel 4 .

Drainase atau saluran pembuangan air pada sumur gali merupakan persyaratan sanitasi yang juga harus dipenuhi agar terlindung dari kontaminasi air kotor. Drainase harus dibuat bersambungan dengan parit agar tidak terjadi genangan air disekitar sumur. ${ }^{9}$ Data yang terlihat pada Tabel 4 didapatkan bahwa sebanyak 53,33\% sumur gali yang diperiksa memiliki saluran pembuangan air yang menyambung ke parit. Sisanya sebanyak 46,66\% tidak memiliki saluran pembuangan air ke parit. Pada semua sumur gali yang memenuhi standar memiliki saluran pembuangan air atau drainase. Sedangkan sebanyak $63,6 \%$ dari sumur gali yang tidak memenuhi standar tidak memiliki drainase atau saluran pembuangan air yang menyambung ke parit.

Tutup sumur juga mempengaruhi kualitas air bersih didalamnya. Sumur sebaiknya ditutup dengan penutup yang terbuat dari batu dan semen terutama 
pada sumur umum. Tutup sumur seperti ini dapat mencegah kontaminasi langsung terhadap sumur., ${ }^{2,9}$ Pada Tabel 4, jenis tutup sumur yang banyak digunakan pada sumur gali yang diperiksa adalah seng, yaitu sebanyak 54\%. Pada sumur gali yang menggunakan seng sebagai penutupnya ini, didapatkan hasil kualitas air sumur gali yang tidak memenuhi standar atau memiliki jumlah Coliform > 50 pada setiap $100 \mathrm{ml}$ air. Sedangkan pada semua sumur gali, yang airnya memenuhi standar kualitas yang ditetapkan Permenkes menggunakan penutup yang terbuat dari semen.

Faktor lain yang mempengaruhi kualitas air bersih sumur gali adalah dinding sumur dan dinding yang membatasi mulut sumur dari permukaan tanah (dinding parapet). Dinding sumur harus dilapisi dengan batu yang disemen (polongan). Pelapisan dinding tersebut paling tidak sedalam 6 meter dari permukaan tanah. Sumur yang tidak dilapisi dengan batu yang disemen ini lebih memudahkan terjadinya kontaminasi lansung pada air sumur. ${ }^{2,9}$ Pada semua sumur gali yang diperiksa mengunakan palapisan dengan batu yang disemen. Sedangkan untuk dinding parapet harus dibuat setinggi $70-75 \mathrm{~cm}$ dari permukaan tanah. Dinding ini merupakan satu kesatuan dengan dinding sumur. Terdapat 5 dari 15 sumur gali yang diperiksa atau 33,33\% memiliki dinding parapet $<75$ $\mathrm{cm}$. Sumur gali yang memiliki dinding parapet $<75 \mathrm{~cm}$ ini menunjukkan hasil kualitas air sumur gali yang tidak memenuhi standar. Sisanya sebanyak $66,66 \%$ atau sebanyak 10 dari 15 sumur gali yang diperiksa meiliki dinding parapet $>75 \mathrm{~cm}$ atau ditutup dan diratakan dengan lantai semen. Hal ini bisa dilihat pada Tabel 4

\section{KESIMPULAN}

Sebagian besar sumur gali tidak memenuhi standar yang ditetapkan Permenkes R.I. no. 416 tahun 1990 tentang syarat-syarat dan pengawasan kualitas air. Ditemukan sebanyak $73,33 \%$ dari jumlah sumur yang diperiksa tidak memenuhi standar karena mengandung Coliform >50 pada setiap $100 \mathrm{ml}$ air, seperti yang terlihat pada diagram 1. Hanya $26,6 \%$ sumur yang diperiksa memenuhi standar yang telah ditetapkan.

\section{UCAPAN TERIMA KASIH}

Terima kasih kepada semua pihak yang telah membimbing dan membantu dalam menyelesaikan penelitian ini. Terima kasih juga kepada pihak Dinas Kesehatan Provinsi Sumatra Barat, Dinas Kesehatan Kota Padang, Puskesmas Lubuk Buaya, dan ibu kader, serta warga Kelurahan Lubuk Buaya, yang telah membantu penulis dalam rangka menyelesaikan penelitian ini.

\section{DAFTAR PUSTAKA}

1. World Health Organization (WHO). Environmental health. Januari 2008 (diunduh 20 April 2012). Tersedia dari: URL: HYPERLINK http://www.WHO.int

2. Chandra B. Pengantar kesehatan lingkungan. Edisi ke-1. Jakarta: EGC; 2007.

3. Peraturan Menteri Kesehatan Republik Indonesia (PERMENKES R.I) no: 416/menkes/per/ix/1990. Daftar Persyaratan Kualitas Air Bersih. 1990

4. Suriawiria U. Mikrobiologi air dan dasar-dasar pengolahan buangan secara biologis. Bandung: PT Alumni; 2008.

5. Josephine A, Morello Paul A, Eckel Mizer GH. Laboratory manual and workbook in microbiology applications to patient care. Edisi ke-7. The McGraw-Hill Companies; 2003.

6. Yuncong Li, Migliaccio K. Water quality concepts, sampling, and analyses, Edisi ke-1. USA: Taylor and Francis Group, LLC; 2011.

7. Dinas Kesehatan Kota Padang. Profil kesehatan tahun 2010. Padang: DKK; 2011.

8. Mandal BK, Wilkins EGL, Dunbar EM, MayonWhite RT. Penyakit Infeksi. Edisi Ke-6. Penerbit Erlangga, 2008.

9. Anonim. Spesifikasi sumur gali untuk sumber air bersih. (SNI 03-2916-1992). 1992.

10. Entjang I. Ilmu kesehatan masyarakat. Bandung: PT Citra Aditya Bakti; 1997.

11. Haryanto K. Kesehatan lingkungan. Jakarta: Fakultas Kesehatan Masyarakat Universitas Indonesia; 1985.

12. Yuniarno S. Hubungan kualitas air sumur dengan kejadian diare di DAS Solo (studi kasus di hulu dan hilir Bengawan Solo) (tesis); 2005. 
13. Riset Kesehatan Dasar. Profil kesehatan Indonesia tahun 2010. Jakarta; 2010.

14. Nelasari. Laporan tahunan surveilance Puskesmas Lubuk Buaya. Padang: DKK; 2011.
15. Profil kesehatan lingkungan puskesmas Lubuk Buaya. Padang; 2011.

16. Notoatmodjo S. Metodologi penelitian kesehatan. Jakarta: Rineka Cipta; 2010. 